\title{
Implementasi Metode TOPSIS dalam Sistem Pendukung Keputusan Seleksi Penerima Beasiswa Bidikmisi Berbasis Web
}

\author{
Implementation of TOPSIS Method in Web-based Decision Support System \\ Used for Bidikmisi Scholarship Selection
}

\author{
Tri Widayanti*1, Tony Wijaya ${ }^{2}$ \\ ${ }^{1,2}$ STMIK Pontianak \\ E-mail: ${ }^{* 1}$ d4y4nti@yahoo.com, ${ }^{2}$ mail.tonywijaya@gmail.com
}

\begin{abstract}
Abstrak
Penggunaan sistem pendukung keputusan dapat meningkatkan proses penilaian dalam seleksi Beasiswa bidikmisi sehingga dapat mengurangi subjektivitas pengambilan keputusan. Keputusan ini di dukung oleh beberapa kriteria sehingga dapat terpilih penerima beasiswa bidikmisi sesuai dengan kuota yang telah diberikan Kemenristek Dikti.Penelitian ini berbentuk studi kasus dengan metode research and development yang subjek penelitiannya adalah Politeknik Negeri Pontianak. Sistem pendukung keputusan untuk seleksi penerima beasiswa bidikmisi menggunakan metode TOPSIS berbasis web dengan menggunakan basis data MySQL dan bahasa pemrograman PHP. Metode perancangan aplikasi sistem pengambilan keputusan seleksi penerima beasiswa bidikmisi menggunakan metode Agile dengan pendekatan Extreme Programming yang memiliki tahapan antara lain Planning, Design, Coding, dan Testing yang menggunakan pendekatan Object-Oriented dengan sistem pemodelannya menggunakan UML. Hasil implementasi Metode TOPSIS dalam sistem pendukung keputusan seleksi penerima beasiswa bidikmisi berbasis web menampilkan fitur menu pendaftaran calon peserta bidikmisi, mеnu pengisian kriteria, mеnu penilaian calon peserta, mеnu hasil penilaian, menu kelola kriteria, menu kelola alternatif kriteria dan menu kelola pemakai. Selain itu, hasil implementasi memberikan objektivitas dan kemudahan bagi panitia dalam penilaian dan perankingan. Hasil pengujian juga menunjukkan bahwa penggunaan metode TOPSIS sebagai alternatif pengambilan keputusan dalam seleksi penerima beasiswa bidikmisi dapat menyaring $20 \%$ penerima beasiswa bidikmisi yang seharusnya tidak layak mendapatkan beasiswa tersebut.
\end{abstract}

Kata Kunci - Implementasi, Sistem Pendukung Keputusan, metode TOPSIS, beasiswa bidikmisi, basis web.

Abstract

The use of decision support system can enhance the assessment process of bidikmisi scholarship selection, so that it may reduce the subjectivity in decision making. This decision system is supported by some criteria, so that the reciplent of bidikmisi scholarship can be selected accordance to the provided quota by Kemenristek Dikti. This is a case study research with research and development method where research participant is State Polytechnic School of Pontianak. TOPSIS method is used in decision support system for bidikmisi scholarship acceptance selection web-based using MySQL based data and PHP language program. The application design method of decision support system of bidikmisi scholarship selection recipients use agile method of Extreme Programming approach which steps of Planning, Design, Coding and Testing of object-Oriented approach with UML. The result of TOPSIS method application in decision support system of bidikmisi scholarship selection recipients web-based display fitur menu of bidikmisi candidate registration, prospective participants charging criteria, candidate 
assessment menu, the assessment result menu, management criteria menu, alternative governance criteria and the user governance menu. Basides, the result of the implememtation gives objectivities and ease for the committee in the assessment and ranking. The test results also show that the use TOPSIS method as an alternative decision-making in the selection of awardees bidikmisi can filter $20 \%$ scholarship bidikmisi that should not be eligible for the scholarship.

Keywords - Implementaion, Decision Support System, TOPSIS method, bidikmisi scholarships, web-based.

\section{PENDAHULUAN}

Sistem penunjang keputusan merupakan pendekatan sistematis, yang diawali dengan permasalahan pembuatan keputusan manajemen, pengumpulan fakta-fakta, menetapkan sejumlah kriteria keputusan untuk memilih alternatif-alternatif tindakan yang paling tepat sebagai solusi keputusan. Sistem penunjang keputusan adalah suatu sistem interaktif berbasis komputer yang membantu membuat keputusan dengan memanfaatkan data dan model untuk menyelesaikan persoalan yang bersifat terstruktur dan semi terstruktur. [1] Sistem pendukung keputusan merupakan bagian dari sistem informasi berbasis komputer termasuk sistem berbasis pengetahuan atau manajemen pengetahuan yang dipakai untuk mendukung pengambilan keputusan dalam suatu organisasi atau perusahaan.

Proses seleksi penerimaan beasiswa bidikmisi pada Politeknik Negeri Pontianak (POLNEP) dimulai dari pendaftaran calon peserta yang sudah dilakukan secara online, sedangkan proses penilaian belum menggunakan sistem yang terkomputerisasi sehingga memerlukan waktu yang lama, ketelitian dan kurangnya obyektifitas penilaian. Seleksi penerima beasiswa bidikmisi dilakukan untuk memilih calon mahasiswa yang berprestasi dan kurang mampu secara finasial dengan memenuhi persyaratan atau kriteria yang sudah ditentukan. Adapun kriteria-kriteria yang harus menjadi pertimbangan dalam penilaian calon mahasiswa bidikmisi seperti pekerjaan ayah, pekerjaan ibu, penghasilan ayah, penghasilan ibu, jumlah tanggungan, pendidikan ayah, pendidikan ibu, tempat tinggal orang tua, luas bangunan, luas tanah, prestasi akademis, nilai rapot, urutan kualitas sekolah, prestasi non akademis dan jarak rumah dari pusat kabupaten atau kota. Semakin banyaknya kriteria yang harus dipertimbangkan dalam proses pengambilan keputusan, maka semakin relatif sulit untuk mengambil keputusan terhadap suatu permasalahan. Apalagi jika upaya pengambilan keputusan dari suatu permasalahan tertentu, selain mempertimbangkan berbagai kriteria yang beragam, juga melibatkan beberapa orang pengambil keputusan (multiple criteria decision making). Penerapan Sistem Pendukung Keputusan (SPK) seleksi penerima beasiswa bidikmisi berbasis web bertujuan agar keputusan yang diambil dapat cepat, tepat dan tidak subyektif sehingga diperoleh penerima beasiswa bidikmisi yang sesuai dengan kriteria yang ditetapkan.

Penelitian yang terkait dengan aplikasi metode TOPSIS dalam pendukung keputusan seleksi penerimaan beasiswa bidikmisi berbasis web yang relevan diantaranya adalah Implementasi Metode TOPSIS pada SPK Penentuan Penerima Beasiswa di IST AKPRIND Berbasis Web. Aplikasi ini dirancang menggunakan diagram konteks dan data flow diagram, sedangkan dalam pemrograman menggunakan bahasa pemrograman PHP dengan aplikasi PHP Data Object sebagai koneksi ke database MySQL dan menggunakan Technique for Order by Similarity to Ideal Solution (TOPSIS). Hasil desain ini dalam bentuk aplikasi berbasis web yang berfokus pada pengambilan keputusan. Penggunaan metode Technique for Order by Similarity to Ideal Solution Technique for Order by Similarity to Ideal Solution (TOPSIS) di penerima beasiswa sistem pendukung keputusan Peningkatan Prestasi Akademik (PPA) dan Bantuan Belajar Mahasisswa (BBM) mampu menyediakan alternatif terbaik berdasarkan hasil tertinggi Peringkat.[2] Penelitian lainnya yang terkait dengan aplikasi metode topsis dalam pendukung keputusan seleksi penerimaan beasiswa bidikmisi berbasis web yaitu Sistem Pendukung Keputusan Pemilihan Perumahan Menggunakan Metode TOPSIS Berbasis Web. Sistem ini 
menggunakan metode TOPSIS yang didasarkan pada kedekatan suatu alternatif terhadap solusi ideal atau disebut nilai preferensi dan berbasis web. Sistem dibangun dengan model sekuensi linier, menggunakan bahasa pemrograman Hypertext Preprocessor (PHP) dan sistem manajemen basis data MySQL. Besar nilai preferensi suatu alternatif perumahan menunjukkan tingginya kecenderungan calon pembeli terhadap perumahan tersebut, sehingga alternatif perumahan yang memiliki nilai terbesar akan menjadi keputusan pilihan perumahan yang terbaik bagi calon pembeli. Sistem Pendukung Keputusan ini dapat mendukung pencarian perumahan di Kota Semarang.[3] Sistem Pendukung Keputusan Pemilihan Otobus Menggnakan Metode Topsis Berbasis Web dengan Yii Framework membantu user dalam pemilihan otobus dengan cara memilih lokasi tujuan, tipe bus, fasilitas sesuai dengan yang diinginkan, dan sistem akan memberikan jawaban atas pemilihan tersebut sesuai perhitungan metode TOPSIS. Berdasarkan hasil implementasi dan analisis sistem pada penerapan metode TOPSIS untuk memilih otobus, maka dapat disimpulkan bahwa penerapan metode TOPSIS mampu menjawab permasalahan tersebut. User akan memasukkan kriteria-kriteria bus yang akan digunakan sesuai dengan kebutuhan. Kemudian sistem akan memberikan jawaban sesuai dengan pilihan pengguna dan hitungan menggunakan metode TOPSIS.[4]

Merujuk kepada penelitian sebelumya, penelitian ini mengimplementasikan metode TOPSIS (Technique for Order by Similarity to Ideal Solution) dalam menentukan model dan simulasi seleksi penerima beasiswa bidimisi berbasis web. Metode ini memerlukan kriteriakriteria dan bobot untuk melalukan perhitungannya sehingga akan didapat alternatif terbaik. Kriteria yang digunakan dalam penelitian ini diperoleh dari hasil wawancara dengan panitia seleksi penerimaan beasiswa bidikmisi dan berdasarkan pedoman penyelenggaraan bantuan biaya pendidikan bidikmisi tahun 2015 [5]. Kriteria-kriteria ini untuk selanjutnya dikelola dengan menggunakakan basis data MySQL dan bahasa pemrograman PHP. Sistem ini dibuat berbasis web supaya dapat diintegrasikan dengan sistem pendaftaran yang sudah berbasis online.

\section{METODE PENELITIAN}

Penelitian ini berbentuk studi kasus dengan metode penelitian Research and Development (R\&D). Teknik pengumpulan data dengan cara wawancara, observasi dan dokumentasi. Metode perancangan aplikasi sistem pengambilan keputusan seleksi penerima beasiswa bidikmisi menggunakan metode Agile dengan pendekatan Extreme Programming yang memiliki tahapan antara lain Planning, Design, Coding, dan Testing [6]. Metode ini menggunakan pendekatan Object-Oriented dengan sistem pemodelannya menggunakan UML (Unified Modeling Language). Aplikasi ini dirancang berbasis web menggunakan bahasa pemrograman PHP (Hypertext Preprosessor) dan menggunakan MySQL sebagai databasenya. Adapun aspek penelitian meliputi fitur menu pendaftaran calon peserta bidikmisi, menu pengisian kriteria, menu penilaian calon peserta, menu hasil penilaian, menu kelola kriteria, menu kelola alternatif kriteria dan menu kelola pemakai.

Sistem Pengambilan Keputusan seleksi penerima beasiswa bidikmisi dirancang dengan menggunakan Technique for Order Preference by Similarity to Ideal Solution (TOPSIS). TOPSIS merupakan suatu metode pendukung keputusan yang menggunakan prinsip bahwa alternatif yang terpilih harus mempunyai jarak terdekat dari solusi ideal positif dan terjauh dari solusi ideal negatif dari sudut pandang geometris dengan menggunakan jarak Euclidean untuk menentukan kedekatan relatif dari suatu alternatif dengan solusi optimal.Solusi ideal positif didefinisikan sebagai jumlah dari seluruh nilai terbaik yang dapat dicapai untuk setiap atribut, sedangkan solusi negatif ideal terdiri dari seluruh nilai terburuk yang dicapai untuk setiap atribut [7].TOPSIS mempertimbangkan keduanya, jarak terhadap solusi ideal positif dan jarak terhadap solusi ideal negatif dengan mengambil kedekatan relatif terhadap solusi ideal positif. Berdasarkan perbandingan terhadap jarak relatifnya, susunan prioritas alternatif bisa dicapai. Adapun tahapan dalam menggunakan TOPSIS antara lain adalah membuat matriks keputusan yang ternormalisasi, membuat matriks keputusan yang ternormalisasi terbobot, menentukan matriks solusi ideal positif 
dan matriks solusi ideal negatif, menentukan jarak antara nilai setiap alternatif dengan matriks solusi ideal positif dan matriks solusi ideal negatif, dan menentukan nilai preferensi untuk setiap alternatif.[8]

\section{HASIL DAN PEMBAHASAN}

Perancangan aplikasi sistem penunjang keputusan seleksi penerimaan beasiswa bidikmisi pada Politeknik Negeri Pontianak (POLNEP) ini diawali dengan mengumpulkan semua kebutuhan sistem yang berhubungan dengan seleksi penerimaan beasiswa bidikmisi. Kebutuhan sistem dapat diketahui melalui analisis sistem dengan menggunakan teknik pengumpulan data yaitu wawancara, observasi dan studi dokumentasi. Wawancara dilakukan dengan panitia seleksi penerimaan beasiswa bidikmisi pada Politeknik Negeri Pontianak (POLNEP) dan observasi dilakukan dengan melihat proses penilaian calon penerima beasiswa bidikmisi berdasarkan kriteria-kriteria yang sudah ditentukan oleh panitia. Sedangkan studi dokumentasi dilakukan untuk melihat data dokumen untuk penilaian calon peserta beasiswa bidikmisi di POLNEP yang berupa pedoman penyelenggaraan bantuan biaya pendidikan bidikmisi tahun 2015 dan formulir pendaftaran seleksi penerimaan beasiswa bidikmisi.

Setelah melakukan analisis kebutuhan sistem, tahap selanjunya adalah merancang sistem pendukung keputusan seleksi penerima beasiswa bidikmisi yang berbasis web dengan membentuk arsitektur sistem pendukung keputusan. Arsitektur SPK bertujuan untuk mendiskripsikan rancangan subsistem menejemen data, subsistem manajemen model dan subsistem antarmuka pengguna yang akan dikembangkan dalam perancangan sistem penunjang keputusan seleksi penerima beasiswa bidikmisi. Subsistem manajemen data seleksi penerima beasiswa bidikmisi menggunakan data internal dan database MySQL. Data internal berupa data peserta penerima beasiswa bidikmisi yang masuk di POLNEP, dan data yang dikelola oleh panitia penerima beasiswa bidikmisi yaitu kriteria, alternatif kriteria dan bobot alternatif kriteria. Subsistem manajemen model data yang digunakan adalah TOPSIS dengan bahasa pemograman PHP. Subsistem antarmuka pengguna menggunakan pemodelan sistem berorientasi objek melalui diagram use case, class, activity dan sequence. Gambar 1 adalah arsitektur SPK seleksi penerima beasiswa bidikmisi yang diusulkan.

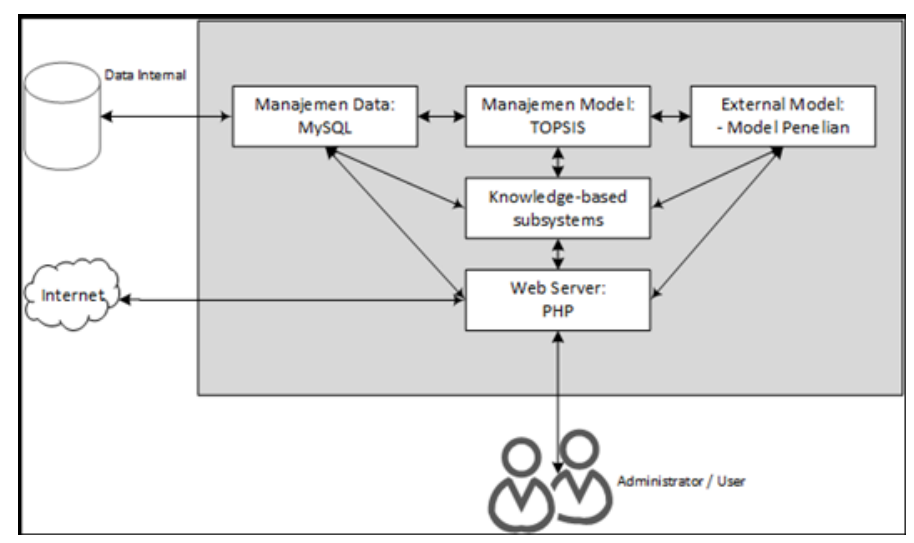

Gambar 1. Arsitektur SPK Seleksi Penerimaan Beasiswa Bidikmisi

Diagram use case menjelaskan manfaat sistem dari sudut pandang orang yang berada di luar sistem atau actor. User dalam hal ini Administratror memiliki fungsi untuk mengelola pengguna sistem beserta password. Panitia seleksi penerima beasiswa bidikmisi berfungsi mengelola kriteria, mengelola alternatif kriteria dan penilaian calon peserta. Sedangkan user calon peserta memiliki fungsi untuk mengisi daftar peserta, mengisi kriteria peserta dan melihat hasil penilaian, seperti ditunjukkan pada Gambar 2. 


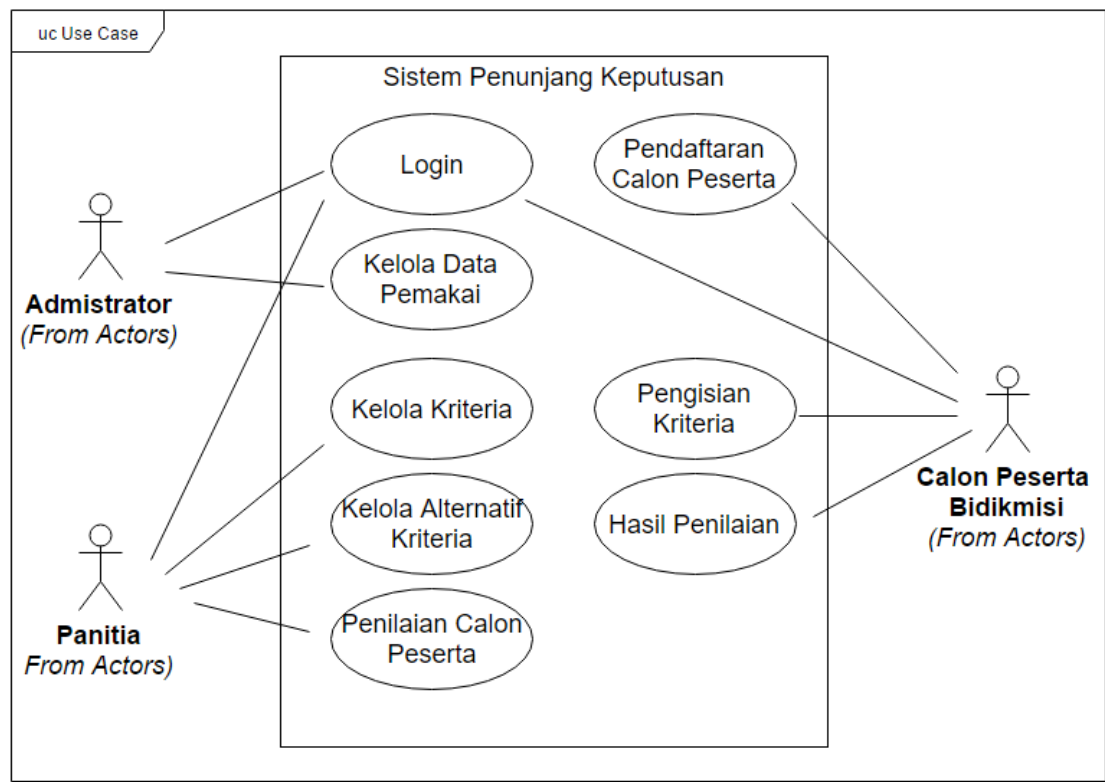

Gambar 2. Use Case Diagram SPK Seleksi Penerimaan Beasiswa Bidikmisi

Penilaian terhadap calon peserta bidikmisi dilakukan setelah nilai kriteria dari tiap-tiap calon sudah masuk. Sistem akan menghitung nilai matriks alternatif dan kriteria, kemudian menghitung matrik keputusan yang ternormalisasi, menghitung matriks keputusan yang ternormalisasi terbobot, penentuan solusi ideal positif dan solusi ideal negatif, dan penghitungan separation measure ideal positif dan ideal negative serta menyimpan hasil nilai penghitungan tersebut ketiap-tiap calon peserta. Activity diagram penilaian calon peserta beasiswa ditunjukkan pada Gambar 3.

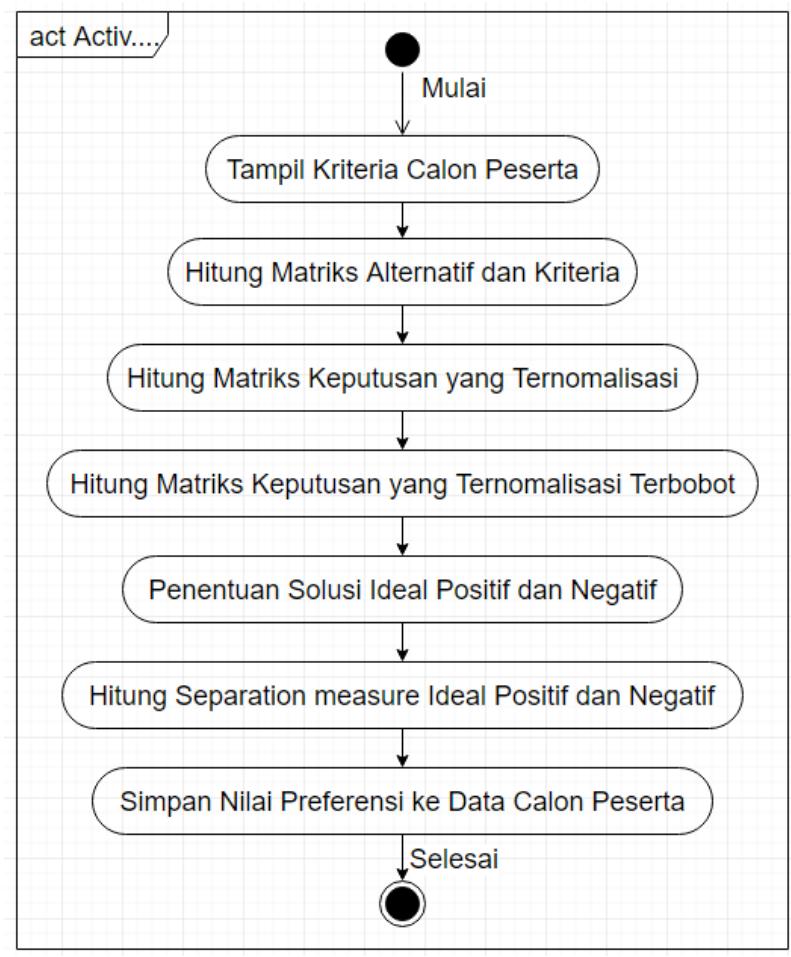

Gambar 3. Activity Diagram Penilaian Calon Peserta Beasiswa Bidikmisi 
Perangkingan dimulai dari panitia memilih periode seleksi penerima beasiswa bidikmisi kemudian sistem akan melakukan penilaian calon peserta berdasarkan nilai kriteria dan sub kriteria yang telah masuk, hasil penilaian akan disimpan yang selanjutnya bisa langsung dicetak. Jika tidak akan dicetak maka akan kembali ke menu awal. Sequence diagram perangkingan ditunjukkan pada Gambar 4.

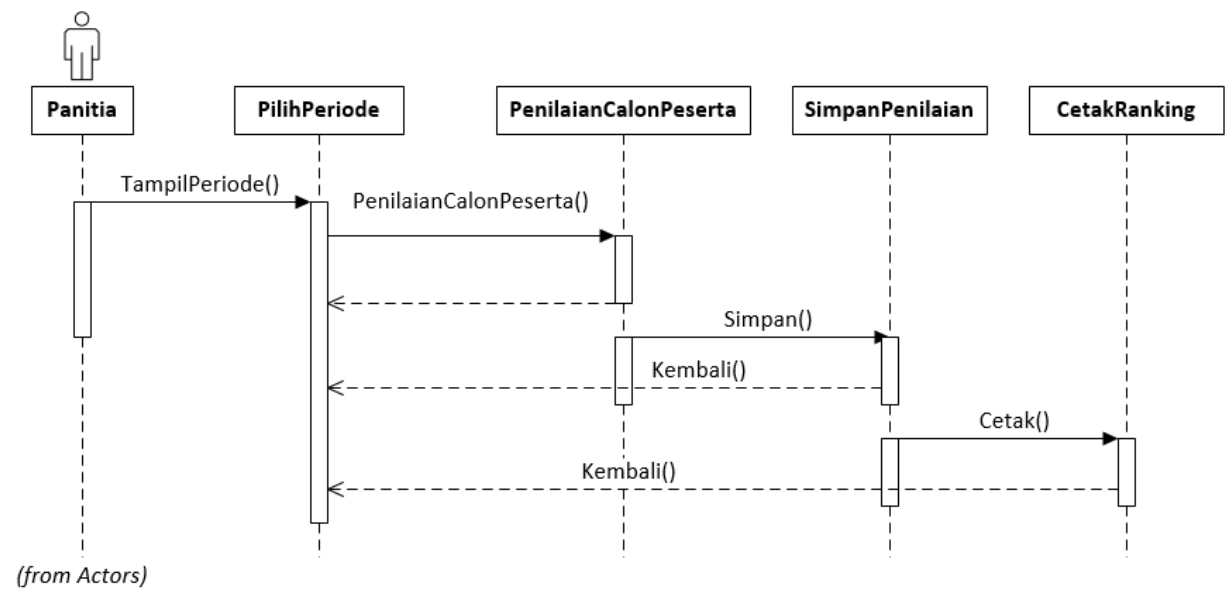

Gambar 4. Sequence Diagram Nilai Preferensi/Perangkingan

Entity Relationship diagram (ERD) digunakan untuk memodelkan kebutuhan data dari sistem penerimaan beasiswa bidikmisi yang digunakan dalam pengembangan sistem pendukung keputusan. Adapun Entity Relationship diagram (ERD) yang terdapat pada sistem pengambilan keputusan untuk seleksi penerima beasiswa bidikmisi terlihat pada Gambar 5.

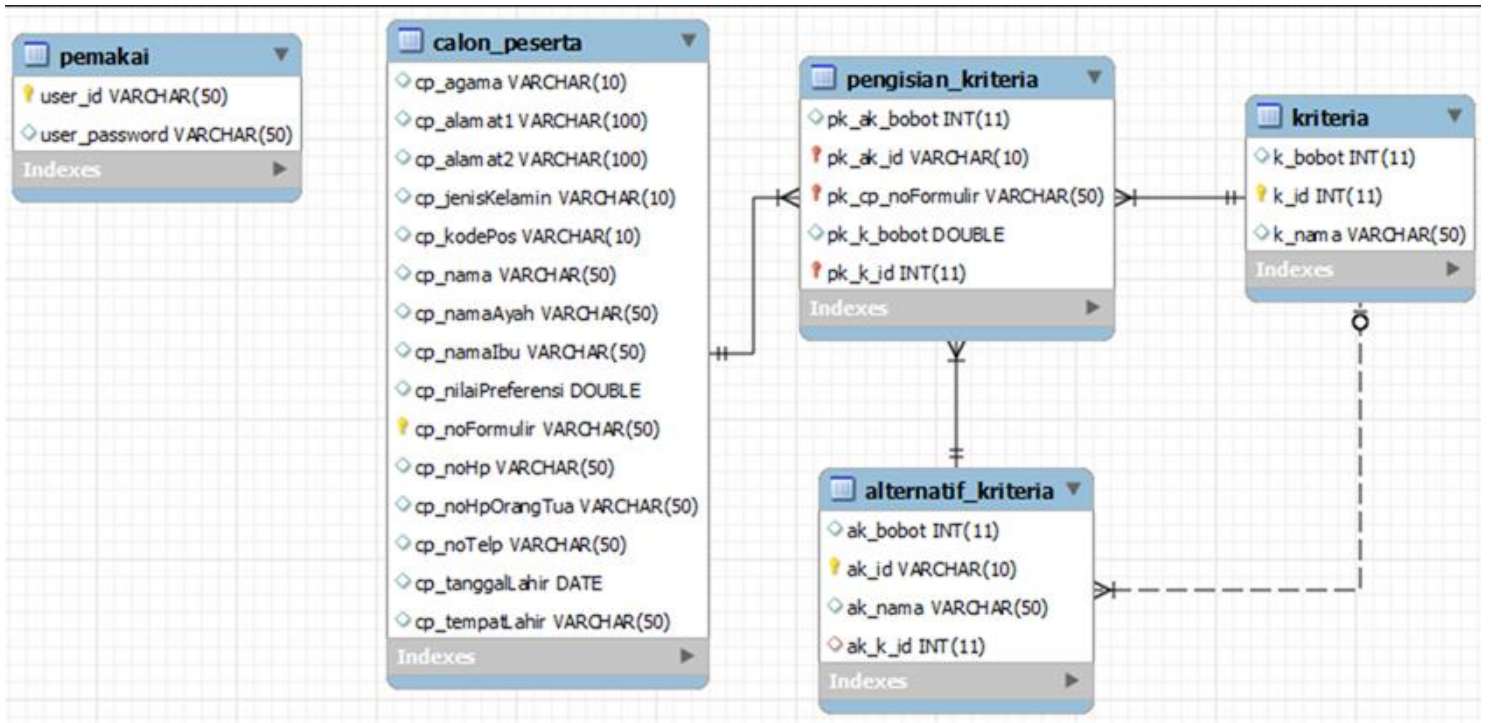

Gambar 5. Entity Relationship diagram SPK Seleksi Penerimaan Beasiswa Bidikmisi

Sedangkan Class diagram digunakan untuk menampilkan beberapa kelas, relasi-relasi serta paket-paket yang ada dalam perangkat lunak atau sistem penunjang keputusan seleksi penerima beasiswa bidikmisi yang dibangun. Class diagram mendeskripsikan jenis-jenis objek dalam sistem dan berbagai macam hubungan statis yang terdapat di antara mereka. Class diagram menunjukkan properti dan operasi sebuah kelas dan batasan-batasan yang terdapat dalam hubungan-hubungan objek tersebut. Class diagram memiliki 3 bagian utama yaitu attribute, operation, dan name. Class diagram SPK seleksi penerimaan beasiswa bidikmisi ditunjukkan pada Gambar 6. 


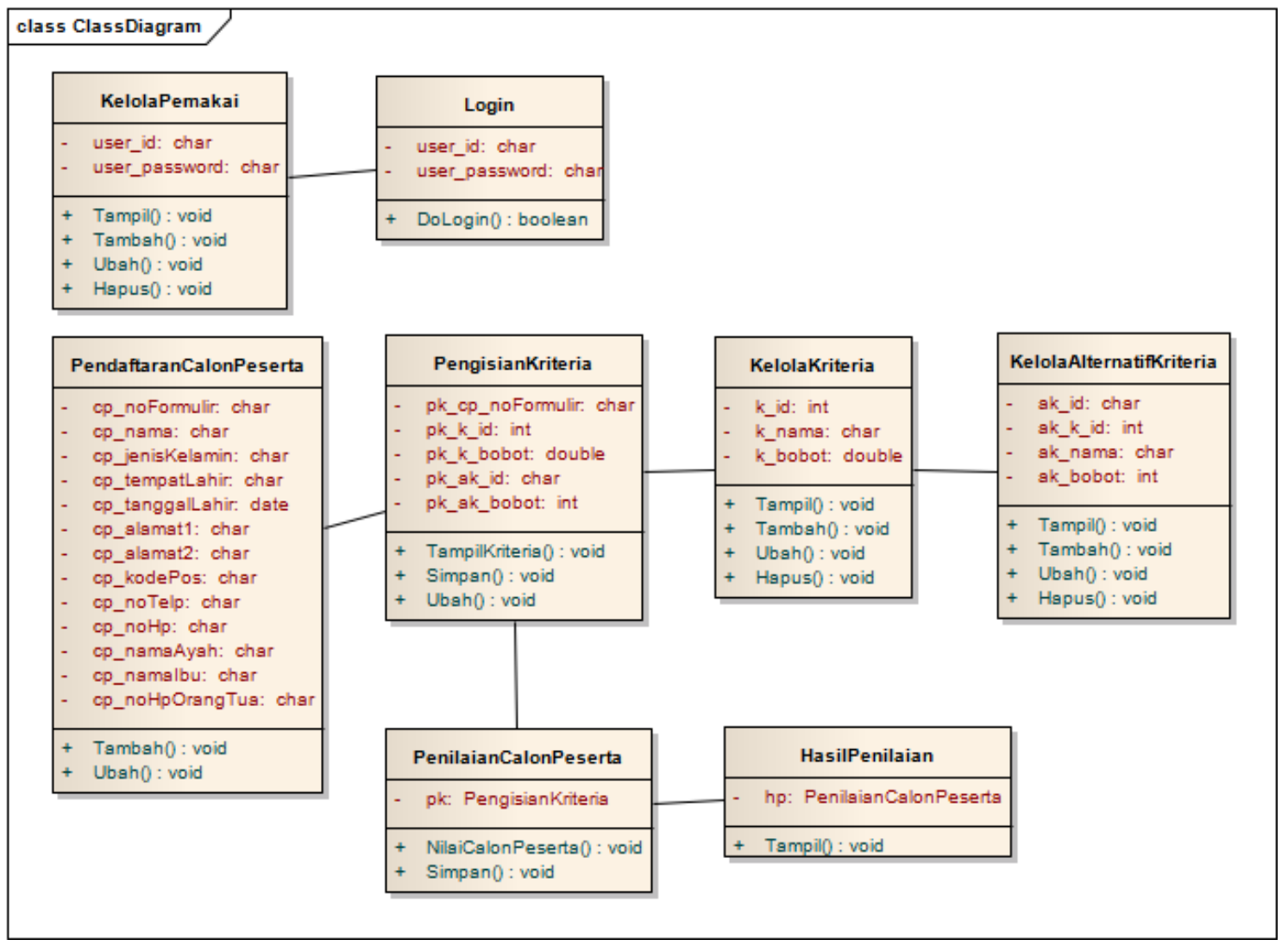

Gambar 6. Class Diagram SPK Seleksi Penerimaan Beasiswa Bidikmisi

Perancangan SPK seleksi penerima beasiswa bidikmisi merupakan program apikasi berbasis web yang dirancang dengan menggunakan bahasa pemograman PHP. Berikut merupakan perancangan halaman utama Sistem Penunjang Keputusan Seleksi Penerimaan Beasiswa Bidikmisi pada Politeknik Negeri Pontianak yang menggunakan metode TOPSIS. Terdapat beberapa menu yaitu menu pendaftaran calon peserta bidikmisi, menu pengisian kriteria, menu penilaian calon peserta, menu hasil penilaian, menu kelola kriteria, menu kelola alternatif kriteria dan menu kelola pemakai, seperti terlihat pada Gambar 7.

Bidikmisi - Sistem Penunjang Keputusan

\begin{tabular}{|c|c|}
\hline Search.. & a \\
\hline \multicolumn{2}{|c|}{ ๑ Beranda } \\
\hline \multicolumn{2}{|l|}{ Login } \\
\hline \multicolumn{2}{|c|}{ [8 Pendataran Calon Peserta } \\
\hline \multicolumn{2}{|c|}{ Cengisian Kriteria } \\
\hline \multicolumn{2}{|c|}{ 男 Peniliaian Calon Peserta } \\
\hline \multicolumn{2}{|c|}{ Lall Hasill Penilaian } \\
\hline \multicolumn{2}{|c|}{ f Kelola Kriteria } \\
\hline \multicolumn{2}{|c|}{ A Kelola Alternatif Kriteria } \\
\hline \& Kelola P & \\
\hline
\end{tabular}

\section{Beranda}

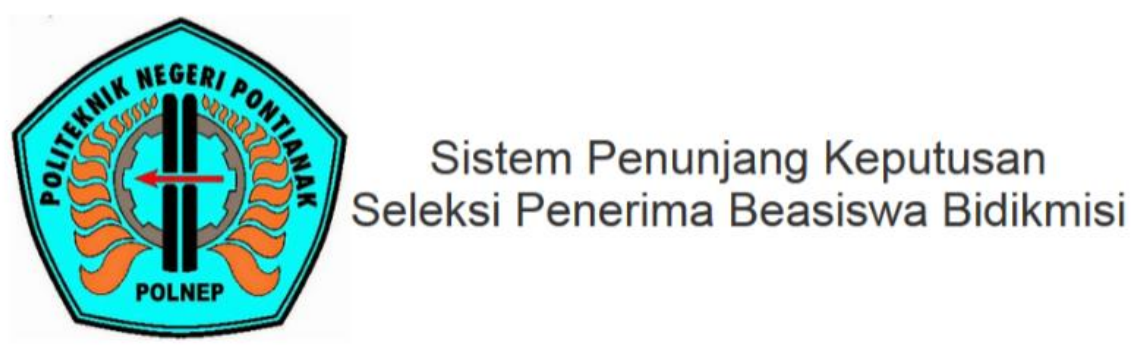

Hak Cipta $\odot 2016$ - Politeknik Negeri Pontianak

Gambar 7. Hasil Rancangan Halaman Utama

Gambar 8 menunjukan tampilan pendaftaran calon peserta beasiswa bidikmisi. Tampilan ini berfungsi untuk memanipulasi data calon peserta bidikmisi yang diinputkan oleh calon peserta 
secara online dengan terlebih dahulu melakukan login. Data yang harus diisi calon peserta beasiswa bidikmisi adalah nama, jenis kelamin, tempat dan tanggal lahir, agama, alamat, kode pos, no Hp, no telp, nama ayah, nama ibu, dan no Hp orang tua. Jika data calon peserta sudah diisi, langkah selanjutnya yang harus dilakukan adalah mengisikan kriteria calon peserta. Kriteria yang diinputkan dan alternatif kriteria digunakan untuk mengisi matriks alternatif dan kriteria.

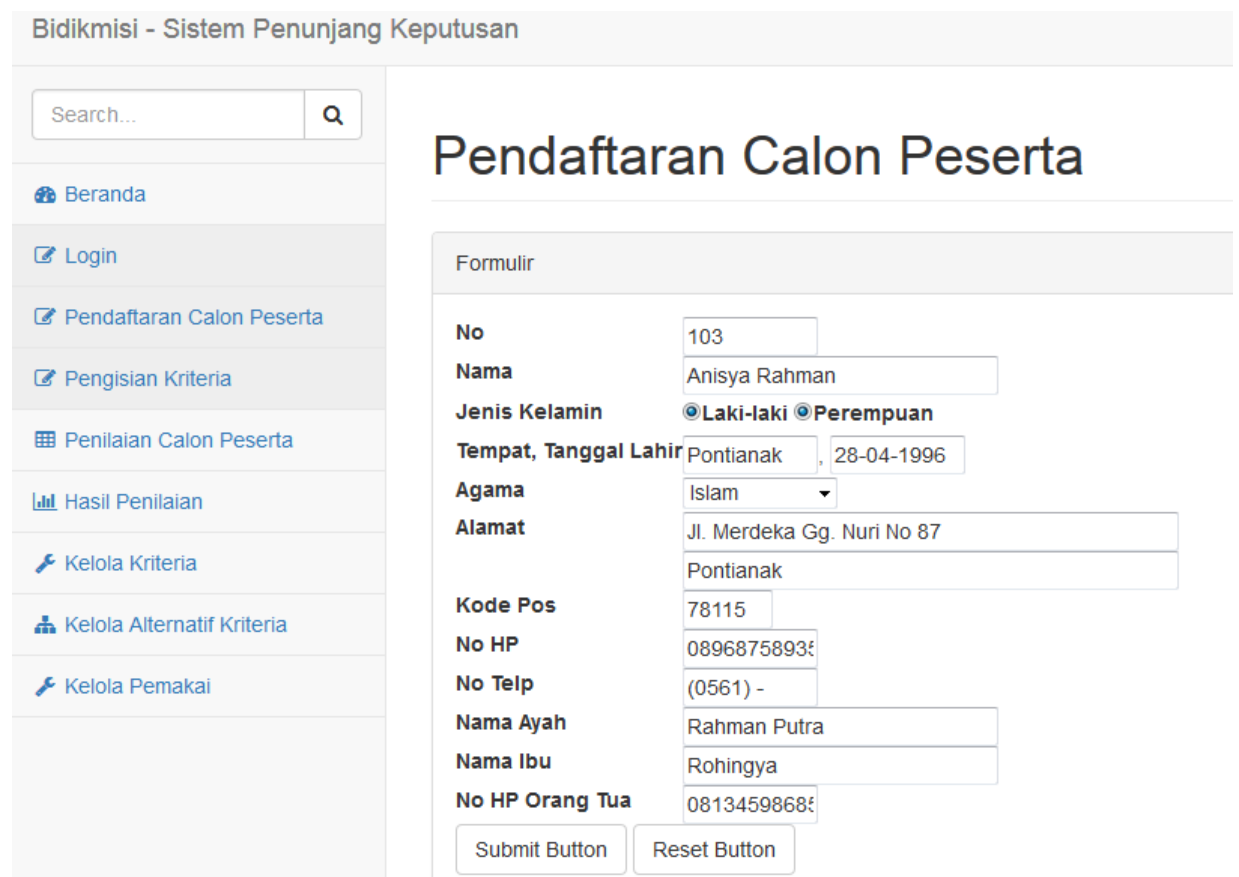

Gambar 8. Hasil Rancangan Form Pendaftaran Calon Peserta

Proses TOPSIS dapat dilakukan ketika data peserta, kriteria peserta, dan nilai bobot kriteria sudah diinputkan. Data peserta dan kriteria peserta diinputkan oleh peserta, sementara nilai bobot kriteria diinputkan oleh panitia. Nilai bobot kriteria ditentukan berdasarkan kepentingan antara tiap kriteria. Semakin tinggi nilai suatu kriteria, maka semakin tinggi tingkat kepentingan kriteria tersebut dalam menarik sebuah keputusan untuk menentukan penerima beasiswa bidikmisi yang baik. Seperti terlihat pada Gambar 9 . 


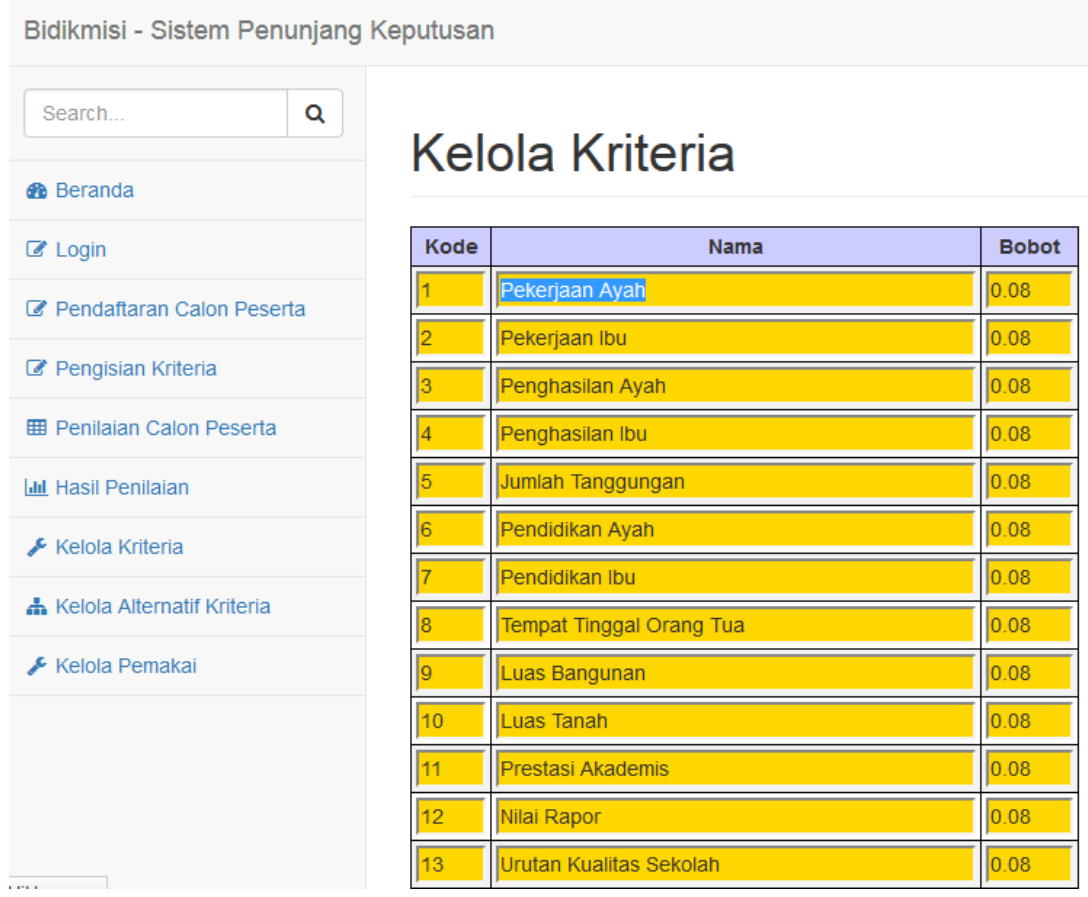

Gambar 9. Hasil Rancangan Form Pengisian Kriteria

Berdasarkan biodata dan kriteria yang diinputkan, peserta akan dilakukan proses penghitungan yang dimulai dari matriks alternatif dan kriteria, matriks keputusan yang ternormalisasi, matriks keputusan yang ternormasisasi terbobot, solusi ideal positif (A+), solusi ideal negatif (A-), separation measure ideal positif $(\mathrm{S}+)$ dan separation measure ideal negatif (S-) seperti pada tampilan Gambar 10.

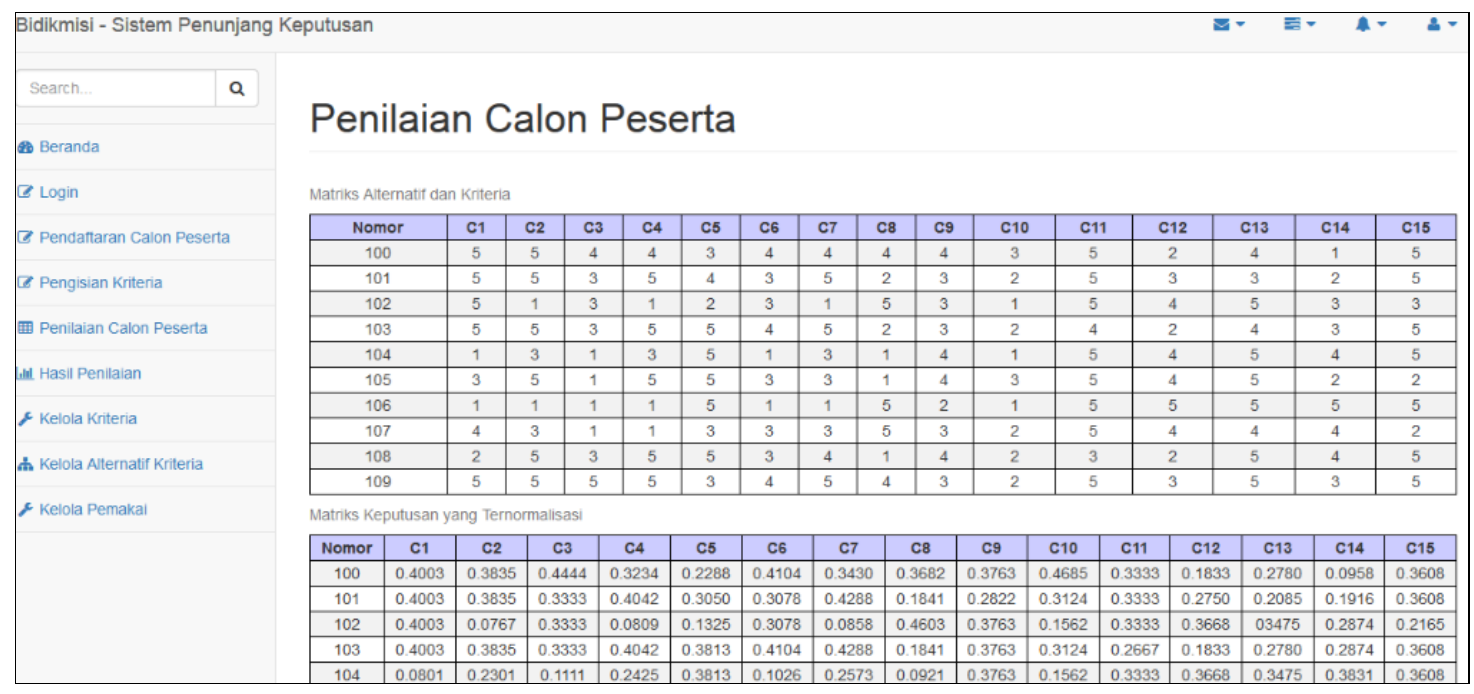

Gambar 10. Hasil Rancangan Form Penilaian Calon Peserta

Hasil penilaian calon peserta bidikmisi ditampilkan pada Gambar 11 dengan urutan perangkingan yang dimulai dari nilai tertinggi. Rangking 1 yaitu nomor peserta 109 yang memiliki hasil penilian yang tertinggi, rangking 2 nomor peserta 100 yang memiliki penilaian dibawah nomor 109, rangking 3 nomor peserta 103 yang memiliki penilaian dibawah nomor 100 dan diikuti oleh peserta yang memiliki penilaian yang semakin kecil. Jumlah peserta bidikmisi yang diterima sesuai dengan quota yang sudah di tetapkan oleh panitia. 
Citec Journal, Vol. 3, No. 4, Agustus 2016 - Oktober 2016

Bidikmisi - Sistem Penunjang Keputusan

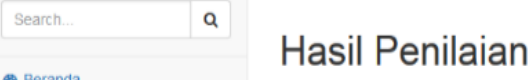

8 Login Nilai-nilai Hasil Perangkingan

G Pendanaran Calon Peserta

(8) Pengisian Kriteria

mit Peniaian Calon Peserta

แhL Hasil Penilaian

\& Kelola Kriteria

A Kelola Allematir Kriteria

$\boldsymbol{s}$ Kelola Pemakai

Nilai-nilai Hasi Perangkngan
\begin{tabular}{|c|c|c|c|c|}
\hline Nomor & Nama & $\mathbf{s}^{*}$ & $\mathbf{S}^{*}$ & Nilai Preferensi \\
\hline 109 & Yuliani & 0.0245 & 0.0742 & 0.7518 \\
\hline 100 & Dede Febrianto & 0.0283 & 0.0700 & 0.7121 \\
\hline 103 & Anisya Rahman & 0.0374 & 0.0656 & 0.6369 \\
\hline 101 & Klara Putri & 0.0374 & 0.0616 & 0.6222 \\
\hline 108 & Harinatar & 0.0469 & 0.0566 & 0.5469 \\
\hline 105 & Agung Saputra & 0.0520 & 0.0583 & 0.5286 \\
\hline 107 & Totok Putranto & 0.0529 & 0.0490 & 0.4809 \\
\hline 102 & Mia Anggelina & 0.0768 & 0.0490 & 03895 \\
\hline 106 & EKo Riyani & 0.0735 & 0.0424 & 03658 \\
\hline 104 & Ari Firmansyah & 0.0678 & 0.0387 & 0.3634 \\
\hline
\end{tabular}

Hak Cipta @ 2016 - Politeknik Negeri Pontianak

Gambar 11. Hasil Penilaian Calon Peserta Bidikmisi

Pengujian sistem yang dimaksudkan untuk menguji apakah sistem pendukung kepututusan yang dibangun sudah sesuai dengan kebutuhan fungsional atau belum. Sesuai dengan kebutuhan fungsional yaitu memperoleh perbedaan yang signifikan dari sistem manual (sistem yang lama) dengan sistem yang baru. Berikut merupakan perbandingan sistem yang lama dengan sistem yang baru dapat dilihat pada Tabel 1 .

Tabel 1. Perbandingan Pengujian Sistem

\begin{tabular}{|c|l|c|c|}
\hline No. & Nama Calon Peserta & $\begin{array}{c}\text { Hasil Penilaian dengan } \\
\text { Sistem yang Lama }\end{array}$ & $\begin{array}{c}\text { Hasil Penilaian dengan } \\
\text { Sistem yang Baru }\end{array}$ \\
\hline 1 & Dede Febrianto & Diterima & Diterima \\
\hline 2 & Klara Putri & Diterima & Diterima \\
\hline 3 & Donny Akhmad & Diterima & Tidak Diterima \\
\hline 4 & Robby Ansyah & Diterima & Diterima \\
\hline 5 & Rizky Rosihan & Diterima & Diterima \\
\hline 6 & Rika Riyanti & Diterima & Diterima \\
\hline 7 & Fatdli & Diterima & Tidak Diterima \\
\hline 8 & Eduardus Imam & Diterima & Tidak Diterima \\
\hline 9 & Yudiyanto & Diterima & Diterima \\
\hline 10 & Gunandar & Diterima & Diterima \\
\hline 11 & Selamet Sariadi & Diterima & Diterima \\
\hline 12 & Muthiaulia & Diterima & Diterima \\
\hline 13 & Puji Laksono & Diterima & Diterima \\
\hline 14 & Tiara Anggraini & Diterima & Diterima \\
\hline 15 & Junanda Putra & Diterima & Tidak Diterima \\
\hline 16 & Restika Hanitha & Diterima & Diterima \\
\hline 17 & Risky Suci & Diterima & Tidak Diterima \\
\hline 18 & Bambang Sindam & Diterima & Diterima \\
\hline 19 & Lisa Sylvia & Diterima & Diterima \\
\hline 20 & Fadli Safawi & Diterima & Diterima \\
\hline 21 & Tri Jayanti & Diterima & Tidak Diterima \\
\hline 22 & M. Reyhan & Diterima & Diterima \\
\hline 23 & Mindya D. & Diterima & Diterima \\
\hline 24 & Wahaki & Diterima & Diterima \\
\hline 25 & Suci Ramadiani & Diterima & Diterima \\
\hline 26 & R. Wulandari & Diterima & Diterima \\
\hline 27 & Tisna Saputra & Diterima & Diterima \\
\hline & & & \\
\hline & & & a \\
\hline
\end{tabular}


Tabel 1. Perbandingan Pengujian Sistem (lanjutan)

\begin{tabular}{|c|l|c|c|}
\hline No. & Nama Calon Peserta & $\begin{array}{c}\text { Hasil Penilaian dengan } \\
\text { Sistem yang Lama }\end{array}$ & $\begin{array}{c}\text { Hasil Penilaian dengan } \\
\text { Sistem yang Baru } \\
\text { Tidak Diterima }\end{array}$ \\
\hline 28 & Evi Fania & Diterima & Diterima \\
\hline 29 & Mia Anggelina & Diterima & Diterima \\
\hline 30 & Anisya Rahman & Diterima & Diterima \\
\hline 31 & Ari Firmansyah & Diterima & Diterima \\
\hline 32 & Agung Saputra & Diterima & Diterima \\
\hline 33 & Eko Riyani & Diterima & Diterima \\
\hline 34 & Totok P. & Diterima & Diterima \\
\hline 35 & Yuliani & Diterima & Diterima \\
\hline 36 & Herinatar & Diterima & Diterima \\
\hline 37 & Fathiya P. & Diterima & Diterima \\
\hline 38 & Tazkia N. & Diterima & Tidak Diterima \\
\hline 39 & Agung B. & Diterima & Diterima \\
\hline 40 & Santoso & Diterima & Diterima \\
\hline 41 & Intan Puspita Sari & Tidak Diterima & Diterima \\
\hline 42 & Afifah Chintya Putri & Tidak Diterima & Diterima \\
\hline 43 & Rafi Hanif & Diterima & Tidak Diterima \\
\hline 44 & Bagas Prakasa & Diterima & Diterima \\
\hline 45 & Ardilia Azzahra & Tidak Diterima & \\
\hline
\end{tabular}

Berdasarkan hasil uji pada Tabel 1, terlihat perbandingan antara sistem lama dengan sistem baru yang menunjukan masih banyak penerima beasiswa bidikmisi yang seharusnya tidak berhak menerima beasiswa bidikmisi bisa mendapatkan beasiswa bidikmisi. Pada sistem yang lama tercatat 42 sampel peserta yang mendapatkan beasiswa bidikmisi dan dan 3 sampel peserta yang tidak diterima. Setelah dilakukan perhitungan menggunakan sistem baru ternyata diperoleh sebanyak 9 peserta atau $20 \%$ peserta yang tidak layak mendapatkan beasiswa bidikmisi dan $80 \%$ yang dinyatakan layak mendapatkan beasiswa bidikmisi. Selain itu juga, 3 peserta yang ditolak dengan menggunakan penghitungan sistem yang lama, ternyata diterima pada proses penghitungan menggunakan sistem baru.

Durasi waktu penilaian yang relatif lama pada sistem lama memberikan peluang kepada pihak-pihak tertentu, terutama para pengambil keputusan untuk melakukan intervensi terhadap kriteria-kriteria yang menjadi pertimbangan penilaian sehingga berpengaruh terhadap hasil penilaian dan mengurangi objektivitas penilaian tersebut. Sedangkan sistem yang baru memberikan penilaian lebih obyektif karena kriteria-kriteria yang diinputkan calon penerima beasiswa bidikmisi langsung dinilai oleh sistem dimana kriteria-kriteria tersebut tidak bisa diubah oleh panitia seleksi calon penerima beasiswa bidikmisi

\section{KESIMPULAN}

Berdasarkan hasil dan pembahasan, maka dapat diambil kesimpulan bahwa implementasi sistem pendukung keputusan metode TOPSIS pada seleksi penerima beasiswa bidikmisi berbasis web dapat membantu memberikan objektivitas dan kemudahan bagi panitia dalam penilaian dan perankingan. Selain itu, hasil implementasi sistem dibuat berbasis web supaya dapat terintegrasi dengan sistem pendaftaran calon peserta bidikmisi yang sudah berbasis online. Berdasarkan pengujian sistem yang dilakukan, penggunaan sistem pendukung keputusan yang baru dengan metode TOPSIS dalam seleksi penerima beasiswa bidikmisi dapat menyaring $20 \%$ penerima beasiswa bidikmisi atau 9 mahasiswa penerima beasiswa bidikmisi yang tidak layak mendapatkan beasiswa tersebut dan dapat menyaring 3 mahasiswa yang harusnya diterima tetapi tidak diterima pada sistem yang lama. 


\section{SARAN}

Untuk penelitian selanjutnya, dalam Implementasi Metode TOPSIS dalam Sistem Pendukung Keputusan Seleksi Penerima Beasiswa Bidikmisi Berbasis Web dapat menambahkan metode lain sehingga bisa mendapatkan hasil yang lebih baik.

\section{DAFTAR PUSTAKA}

[1] Kosasi, S., 2015, Sistem Pendukung Keputusan Memilih Tipe Rumah Menggunakan Metode Analytic Hierarchy Process, Seminar Nasional Teknologi Informasi dan Komunikasi (SNASTIKOM 2015), Medan, 1-2 September 2015

[2] Agetia, I, W, A., Suraya., Yuliana, R., 2015, Implementasi Metode TOPSIS pada SPK Penentuan Penerima Beasiswa di IST Akprind Berbasis Web, Jurnal Script, Vol. 2, No. 2

[3] Diyah S, P. N., Sasongko, P. S., Sugiharto, A., 2013, Sistem Pendukung Keputusan Pemilihan Perumaham Menggunakan Metode TOPSIS Berbasis Web, Journal of Informatics and Technology, Vol. 2, No. 2, Hal 1-8.

[4] Sudrajat, F. A., Nuryana, I. K. D., 2014, Sistem Pendukung Keputusan Pemilihan OTOBUS Menggunakan Metode TOPSIS Berbasis Web dengan Yii Framework, Jurnal Manajemen Informatika, Vol. 1, No.1, Hal 9-15.

[5] Departemen Pendidikan Nasional, 2010, Buku Panduan Program Beasiswa Bidik Misi (Online), http://bidikmisi.kemdikbud.go.id/portal/, diakses 27 Januari 2016.

[6] Pressman, R., 2005, Software Engineering: a Practitioner's Approach, Sixth Edition, Singapore, Mcgraw-Hill.

[7] Hwang, C L., Yoon, K., 1981, Multiple Attribute Decision Making: Methods and Applications A State-of-the-art Survey, Berlin, Springer-Verlag.

[8] Kusumadewi, S., Hartati, S., Harjoko, A., Wardoyo, R., 2006, Fuzzy Multi-Atribute Decision Making, $I^{s t}$ Edition ed., Yogyakarta, Graha Ilmu. 